\title{
CONTRIBUTIONS Beiträge zur Entomologie

\section{The relationship among the Auletobius species of the subgenus Canarauletes and the description of a new species (Attelabidae: Rhynchitinae)}

\author{
With 6 figures \\ Antonio Verdugo ${ }^{1}$, Peter E. Stüben ${ }^{2}$, Jose L. Torres ${ }^{3}$ and Pedro Coello ${ }^{4}$ \\ ${ }^{1}$ Héroes del Baleares, 10 - 3 B, E-11100 San Fernando, Cádiz, Spain. - averdugopaez@gmail.com \\ 2 Curculio Institute, Hauweg 62, 41066 Mönchengladbach, Germany. - P.Stueben@t-online.de \\ 3 Curculio Institute, Azorín 11, E-11300 La Línea, Cádiz, Spain. - euchloe2@hotmail.com \\ ${ }^{4}$ Milongas, 7, E-11100 San Fernando, Cádiz, Spain. \\ Published on 2020-06-23 \\ DOI:10.21248/contrib.entomol.70.1.189-196
}

\section{Abstract}

A new Auletobius species of the subgenus Canarauletes, Auletobius gaditanus spec. nov., is described from southern Spain. The report that the sister taxon Auletobius maroccanus Hoffmann, 1953 (Locus typicus: Morocco, Reggou, Moyen Moulouya) also occurs in Spain (Almeria: Punta del Sabinar) is corrected, because this specimen also belongs to the new species without doubt. In a morphological and molecular differential diagnosis, the new species is distinguished from the closest related species, and for the first time, a molecular relationship analysis (CO1) is presented for almost all species of the subgenus Canarauletes, whose main distribution area is in the Canary Islands and Madeira.

\section{Taxonomic acts}

Auletobius gaditanus spec. nov. - urn:lsid:zoobank.org:act:17F6BFE9-974E-46B2-BA6E-05624044EAD7

\section{Key words}

Curculionoidea, new species, taxonomy, molecular systematics, morphology, Spain, Portugal, Morocco, Canary Islands, Madeira

\section{Zusammenfassung}

Eine neue Auletobius-Art des Subgenus Canarauletes, Auletobius gaditanus spec. nov., wird aus dem Süden Spaniens beschrieben. Die Meldung, dass die Schwesterart Auletobius maroccanus Hoffmann, 1953 (Locus typicus: Marokko, Reggou, Moyen Moulouya) ebenfalls in Spanien (Almeria: Punta del Sabinar) vorkommt, wird korrigiert. Auch bei diesem Nachweis handelt es sich zweifelsfrei um die neue, hier beschriebene Art, die in einer morphologischen und molekularen Differentialdiagnose (CO1) von den verwandten Arten aus Marokko, den Kanarischen Inseln und Madeira abgegrenzt wird. Für fast alle Canarauletes-Arten wird hier erstmalig ein molekulares Dendrogramm im Diskussionsteil vorgestellt. 


\section{Schlüsselwörter}

Curculionoidea, neue Art, Taxonomie, molekulare Systematik, Morphologie, Spanien, Portugal, Marokko, Kanaren, Madeira

\section{Resumen}

Se describe Auletobius gaditanus spec. nov. del sur de España, una nueva especie de Auletobius del subgénero Canarauletes. El registro de la especie hermana Auletobius maroccanus HoffmanN, 1953 (locus typicus Marruecos: Reggou, Moyen Moulouya) de España (Almería: Punta del Sabinar) es corregido, porque también este espécimen pertenece sin duda a la nueva especie. En una diagnosis diferencial morfológica y molecular (CO1) se distingue la nueva especie de las más próximas, y por vez primera, se presenta un análisis molecular de las relaciones entre casi todas las especies del subgénero Canarauletes, cuya área de distribución principal se encuentra en las islas Canarias y Madeira.

\section{Palabras clave}

Curculionoidea, nueva especie, taxonomía, sistemática molecular, morfología, España, Portugal, Marruecos, Islas Canarias, Madeira

\section{Introduction}

The genus Auletobius Desbrochers Des Loges, 1869 (Attelabidae: Rhynchitinae: Auletini) is represented in the Iberian Peninsula by a single species, based on a record of Auletobius maroccanus Hoffmann, 1953 from Almería (Alonso-Zarazaga, 2002) and another from Cádiz, as Auletobius subgenus Canarauletes spec. (Verdugo, 2019). However, all Iberian records reported so far, which include a specimen from Almería (Punta del Sabinar) and others from Cádiz (three localities) belong to the new species Auletobius gaditanus of the subgenus Canarauletes, which is described here for the first time. The subgenus Canarauletes as presented by LEGALOV in 2007 - with the type species Auletes convexifrons Wollaston, 1864 from Gran Canaria - currently contains six species from Northwest Africa, the Canary Islands and Madeira: A. (C.) convexifrons, A. (C.) anceps (Woll., 1864) from the western Canary Islands, $A$. (C.) cylindricollis (WoLL., 1864) only from La Palma (the reports from Tenerife and Gran Canaria are doubtful and should be verified), A. (C.) garajonay StüBEN, 2015 from La Gomera and El Hierro, A. (C.) maderensis (Woll., 1854) from Madeira (see StüBen 2019) and A. (C.) maroccanus Hoffmann, 1953 from Morocco. Only the latter species is considered by SKUHROVEC et al. (2012) in their digital and interactive key to the West Palearctic Rhynchitidae and Attelabidae, whilst Morris (2004) focused his key on the Macaronesian Auletobius species.

All these species of the subgenus Canarauletes have a long rostrum with the antennae inserted near its base. The elytral striae consist of lines of deep punctures and the elytra show a general reddish-brown and reddishyellow colour. The genus Auletobius DesBrochers Des LOGEs, 1869 is divided into seven subgenera (LEGALOV, 2007), from which the Canarauletes LEGALOV, 2007 differ slightly, for example the Auletobius s. st. species have the insertion of the antennae somewhat further from the base of the rostrum; the Rostauletes Legalov, 2007 have a longer and thinner rostrum, Pseudoparauletes LEGALOV, 2001 species have a strongly curved rostrum in lateral view and also a very wide forehead. Longoauletes LEgALOv, 2007 has a very elongated body; the Micrauletes Legalov, 2003 are characterized by their smaller size and for having small wings, not suitable for flight. Pseudometopum Legalov, 2003 has the base of the pronotum and the elytra finely granulated and finally, the body of Auletobioides LegaLov, 2007 is covered in long, semierect setae.

\section{Auletobius (Canarauletes) gaditanus spec. nov. urn:Isid:zoobank.org:act:17F6BFE9-974E-46B2-BA6E-05624044EAD7}

\section{Description [Fig. 1, 2]}

Type material: Holotype: $1 \sigma^{\star}$, Los Barrios, Cádiz, Pista a Tiradero, $36^{\circ} 12^{\prime} 35^{\prime \prime} \mathrm{N}, 05^{\circ} 32^{\prime} 46^{\prime \prime} \mathrm{W}, 10 . X I I .2018$, leg. A. Verdugo, coll. Senckenberg, Deutsches Entomologisches Institut, (SDEI, Germany, Müncheberg).

Paratypes: $10^{\top}$, E: Los Barrios, Cádiz, Pista a Tiradero, $36^{\circ} 12^{\prime} 35^{\prime \prime} \mathrm{N}, 05^{\circ} 32^{\prime} 46^{\prime \prime} \mathrm{W}, 18.01 .2012$, leg. Torres; 5 o $^{\star \top}$, 6 우 ㅇ․ E: Los Barrios, Cádiz, Pista a Tiradero, $36^{\circ} 12^{\prime} 35^{\prime \prime} \mathrm{N}$, 05³2'46"W, Pistacia lentiscus, 5.12.2018, leg. Verdugo \& Torres; $7 o^{\star} o^{\star}, 6$ 우 우. E: Los Barrios, Cádiz, Pista a Tiradero, $36^{\circ} 12^{\prime} 35^{\prime \prime} \mathrm{N}, 05^{\circ} 32^{\prime} 46^{\prime \prime} \mathrm{W}, 10.12 .2018$, leg. Verdugo; $12 \sigma^{\top} \sigma^{*}, 5$ 우 ㅇ․ E: Cádiz, Chiclana, camino de Camila: Pistacia lentiscus, $36^{\circ} 22^{\prime} 40.2^{\prime \prime} \mathrm{N}, 06^{\circ} 05^{\prime} 09.9^{\prime \prime} \mathrm{W} ; 8.12 .2018$, leg. Coello; $30^{\star} 0^{\star}, 5$ 우 ㅇ. E: Cádiz, Chiclana, camino de Camila: Pistacia lentiscus, 36²2'40.2"N, 0605'09.9"W; 18.12.2018, leg. Coello; 4 o $^{\star}, 2$ 우 우. E: Cádiz, Chiclana, camino de Camila: Pistacia lentiscus, $36^{\circ} 22^{\prime} 40.2^{\prime \prime N}$, 

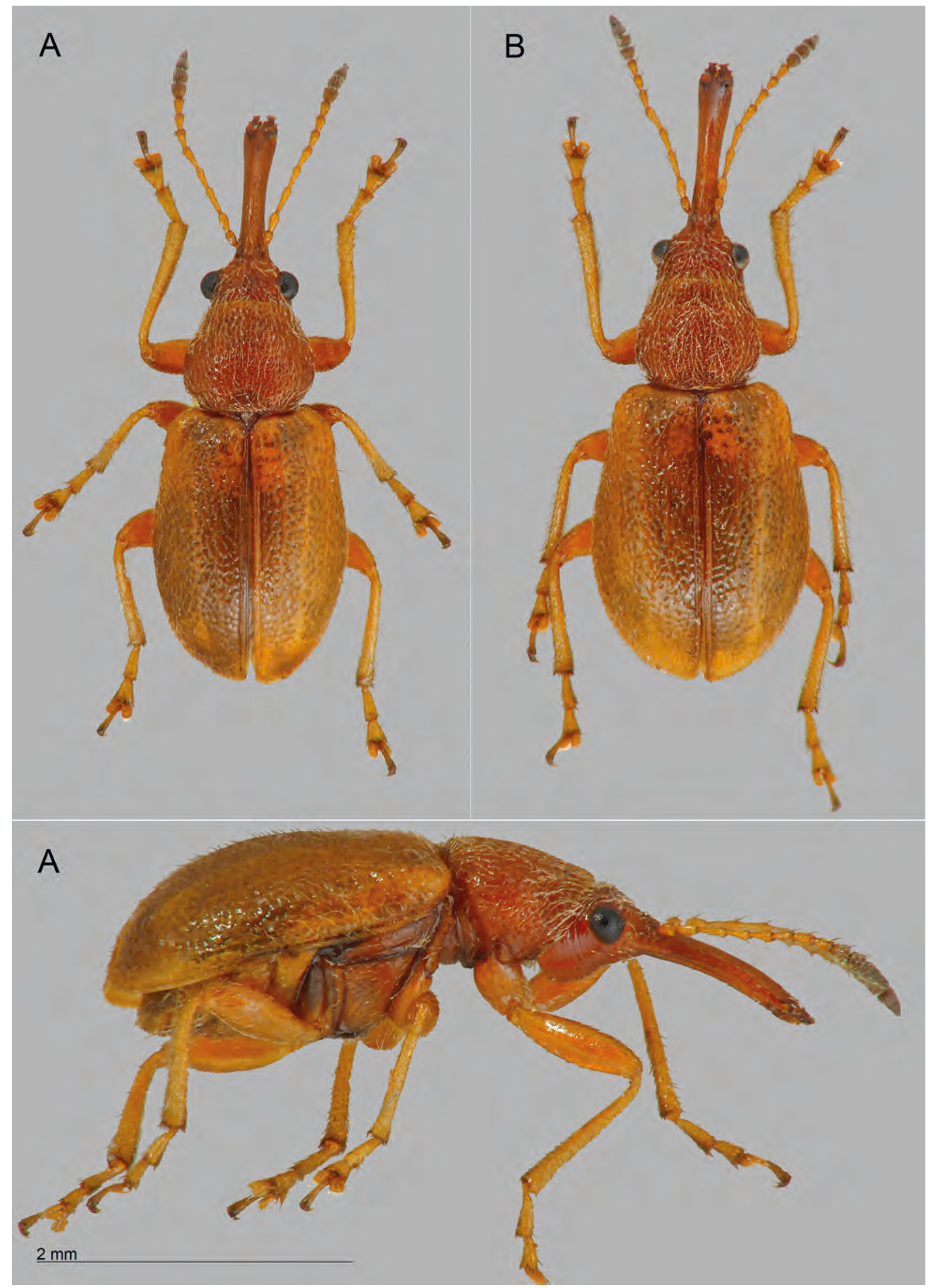

Fig. 1: Auletobius gaditanus spec. nov.: Holotype, male (A), and paratype, female (B), from Spain: Los Barrios (photos by P. E. Stüben). 


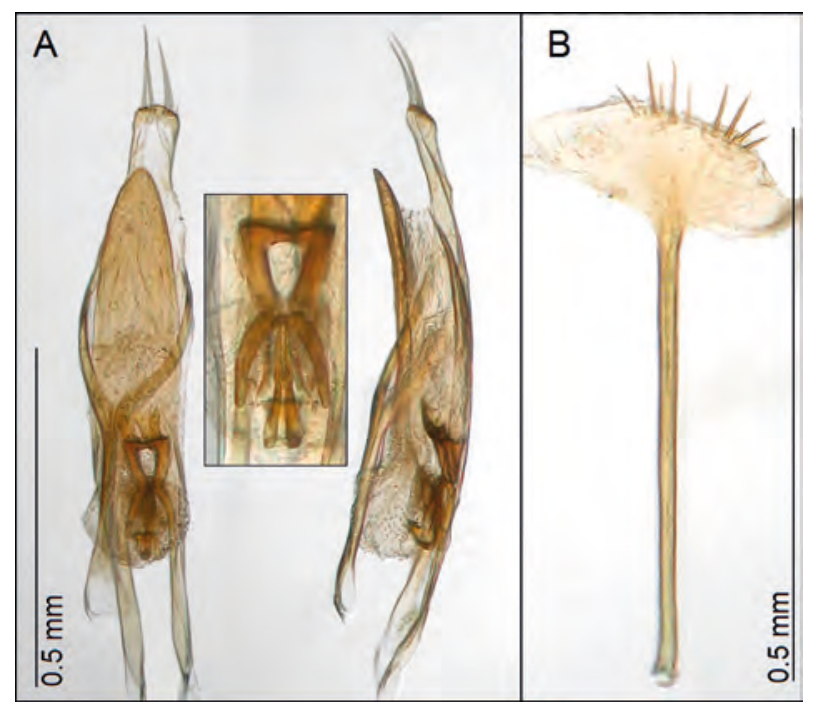

Fig. 2: A Aedoeagus with endophallus of the holotype; B Spiculum ventrale of the female genitalia, paratype (photos by P. E. Stüben).

0605'09.9"W; 12.12.2018, leg. Verdugo \& Coello; 4 ơ ơ, 1 ․ E: Cádiz, Medina Sidonia, El Berrueco: Pistacia lentiscus, $36^{\circ} 26^{\prime} 22.4^{\prime \prime} \mathrm{N}, 06^{\circ} 01^{\prime} 52.9^{\prime \prime} \mathrm{W}, 21.12 .2018$, leg. Verdugo \& Coello; 1 o $^{*}, 3$ ㅇ ㅇ․ E: Cádiz, Chiclana, camino de Camila: Pistacia lentiscus, 36²2'40.2"N, 0605'09.9"W; 26.12.2018, leg. Coello; all Verdugo, Stüben, Torres \& Coello coll.

DNA types (= paratypes): 1 ex., same data as for holotype, collector no.: 3188-AVE; GenBank: MN627733 / 1 ex., E: Cádiz, Medina Sidonia, El Berrueco: Pistacia lentiscus, $36^{\circ} 26^{\prime} 22.4^{\prime \prime} \mathrm{N}, 06^{\circ} 01^{\prime} 52.9^{\prime \prime} \mathrm{W}, 21.12 .2018$, leg. Verdugo \& Coello, collector no.: 3189-AVE; GenBank: MN627734, DNA deposited in Senckenberg Deutsches Entomologisches Institut, (SDEI, Germany, Müncheberg).

Total length $2.3 \mathrm{~mm}-3.2 \mathrm{~mm}$ (excluding rostrum).

Colour: Body without metallic reflections. Dorsal surface of head, pronotum, scutellum and elytra ochraceousyellowish to pale orange, with apex of rostrum and suture of elytra slightly darker. Legs and antennae yellowish, but with antennal club and onychium blackish. Ventral surface with prosternum, mesosternum, lateral margins of metasternum, coxae and trochanters pale orange; disc of metasternum and abdominal sternites black.

Head: Eyes rounded, convex and prominent. Frons with robust and regular punctuation; punctures with white and elongate setae directed forwards. Rostrum about twice longer than pronotum, in dorsal view nine times longer than the width between antennal insertions. Sides of rostrum with white and short setae, 4 or 5 longer setae on the apex. Antennae inserted very close to base of rostrum; $1^{\text {st }}$ antennal segment as long as $2^{\text {nd }} ; 3^{\text {th }}, 4^{\text {th }}$ and $5^{\text {th }}$ segments 1.5 times as long as $1^{\text {st }} ; 6^{\text {th }}, 7^{\text {th }}$ and $8^{\text {th }}$ approx. as long as $1^{\text {st }}$; last three antennal segments $\left(9^{\text {th }}, 10^{\text {th }}\right.$ and $\left.11^{\text {th }}\right)$ forming a club as long as $3^{\text {th }}$ and $4^{\text {th }}$ combined.

Pronotum: Pronotum slightly shorter than its maximum width; in dorsal view basal margin about as wide as anterior margin, sides moderately rounded, maximum width behind middle; surface with long white setae, directed forwards, and with robust and regular punctuation; the space between punctures is equal to the diameter of a puncture.

Scutellum: Equilateral triangle-shaped.

Elytra: Elytra subovoid, 1.5 times longer than wide; presutural interstria elevated; punctuation not uniform, irregularly arranged, confluent close to the distal area; elytral pubescence double, consisting of reclinate, pale yellow setae (directed backwards) and sparse, blackish, erect setae (especially visible on the elytral margin).

Ventral surface: $1^{\text {st }}$ abdominal sternite as long as $2^{\text {nd }}$ and slightly shorter than $3^{\text {th }}+4^{\text {th }}+5^{\text {th }}$ combined; abdominal sternites with whitish pressed setae that are shorter than elytral setae.

Aedeagus / endophallus: See Fig. 1A.

Females: The females are somewhat bigger and equipped with a slightly longer rostrum than the males (see Fig. 1A vs. 1B). Spiculum ventrale of the female genitalia is presented in Fig. 2B.

\section{Morphological differential diagnosis}

The new species has a habitus similar to that of Auletobius (C.) maroccanus (see Fig. 3), but the differences between the two taxa are in fact numerous: the colour of the abdominal sternites is not uniformly orange and the abdominal setae are shorter; the pronotum shows dense dorsal punctuation (in Auletobius maroccanus, the punctuation is sparser and, on the disc, the space between punctures is 2 or 3 times the diameter of a puncture; the elytral punctuation is also sparser and more regulary arranged); elytral setae shorter and thinner; presence of sparse, erect darkish setae on elytral surface (these darkish setae are absent in Auletobius maroccanus). Other differences can also be found in the shape and size of antennal segments: Auletobius gaditanus sp. n. shows the $2^{\text {nd }}$ antennal segment as long as $1^{\text {st }}$; Auletobius maroccanus shows $2^{\text {nd }}$ antennal segment subglobose and shorter.

Preliminary data from molecular markers show that Auletobius gaditanus spec. nov. is closely related to Auletobius (C.) convexifrons (from Gran Canaria), which can be distinguished from the new species by several characters, such as the dimensions of the rostrum (shorter and thicker in A. convexifrons), the shape of the pronotum (cordiform in the new species and with more parallel sides in A. convexifrons), etc.

Etymology: The species name "gaditanus" refers to the Latin name of Cádiz, "gades".

Ecology: All specimens were collected on Pistacia lentiscus from the basal to medium height branches (1.5 m); see Fig. 6 .

Distribution: This species is so far only known from Spain: Almería and Cádiz [Fig. 5]. 


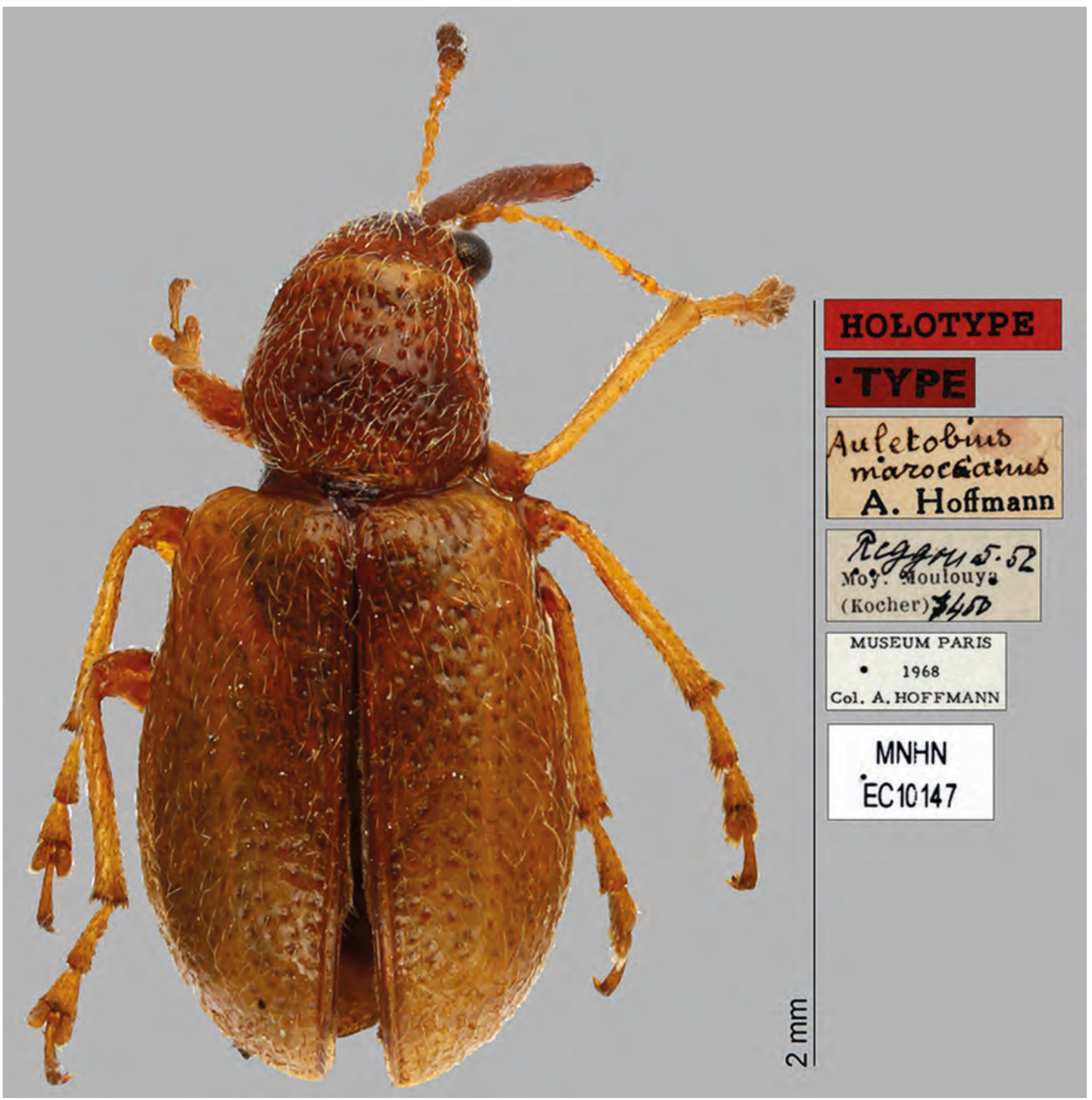

Fig. 3: The comparison species: The holotype of Auletobius maroccanus Hoffmann, 1953 (photo by C. Rivier, MNHN, Paris).

Discussion of the relationship among the Auletobius species of the subgenus Canarauletes

The molecular analysis (Fig. 4) is based on 30 specimens of 8 Auletobius species, including one specimen of Mesauletobius pubescens (Kiesenwetter, 1851) as outgroup. The neighbour joining tree is a subtree of currently 3517 samples of 1493 Curculionoidea species which will be published soon in GenBank. A voucher specimen and extracted genomic DNA have been deposited in the Biobank of the Zoologisches Forschungsmuseum Alexander Koenig, Bonn, Germany (ZFMK) and Senckenberg Deutsches Entomologisches Institut, Müncheberg, Germany (SDEI). Based on the fast evolving Cytochrome c oxidase subunit 1 (COI) gene, the NJ-tree presented here is highly suitable for Alpha taxonomic questions, e.g., showing the systematic position between closely related taxa. The molecular $\mathrm{CO} 1$ sequences of the new species $A$. gaditanus are presented in fasta format in appendix 1 .

The new species Auletobius (Canarauletes) gaditanus from southern Spain forms, together with A. convexifrons from Gran Canaria, the sister taxon of all other Canarauletes species known only from the four western islands of the Canaries: El Hierro, La Palma, La Gomera and Tenerife. The holo- and paratype specimens of A. gaditanus from Cádiz (Los Barrios / 3188-AVE and Medina Sidonia / 3189-AVE) show a genetic distance to the next related species $A$. convexifrons of $6.5 \%$, which is 


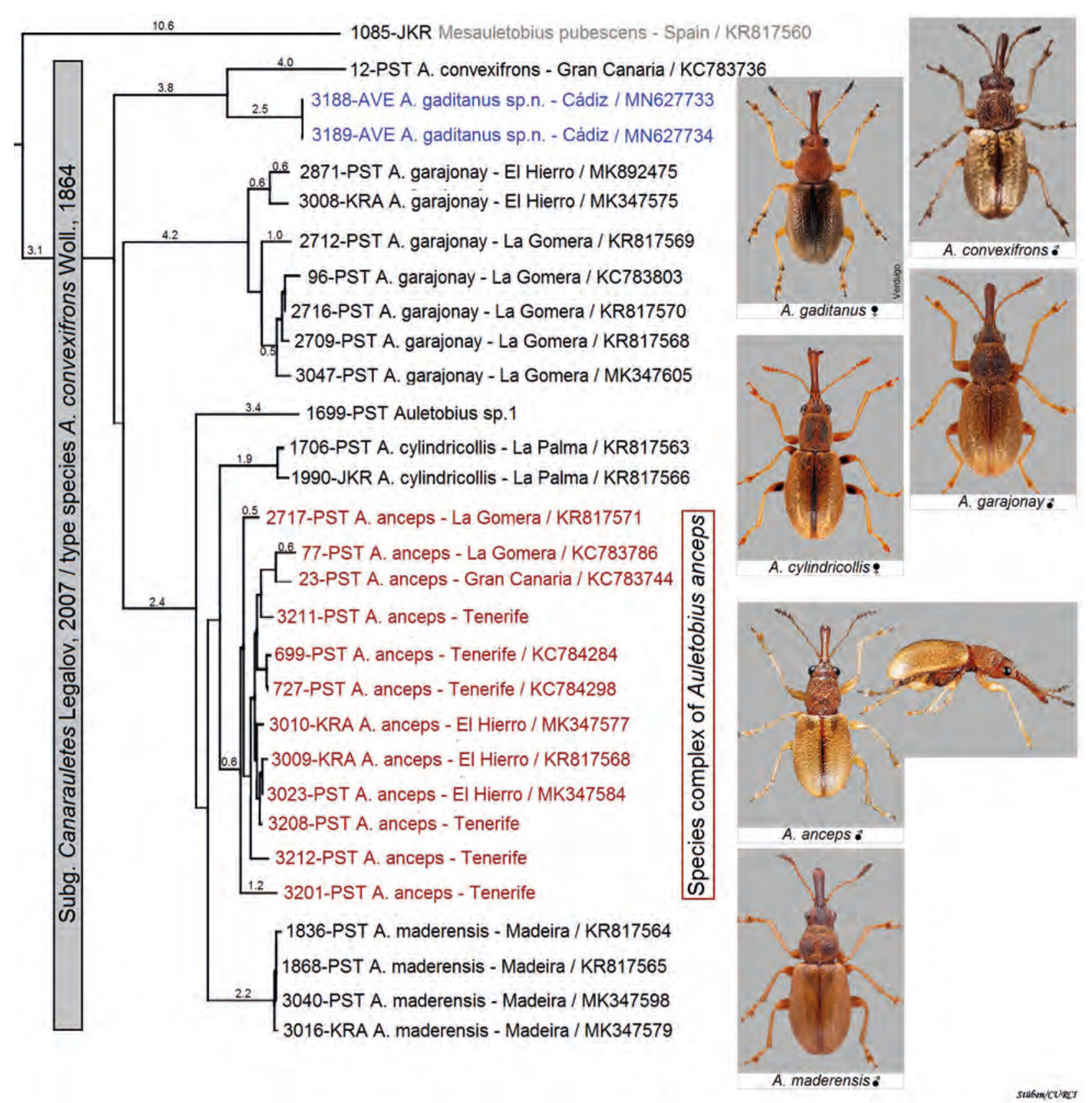

Fig. 4: Neighbour Joining Tree of all Auletobius species of the subgenus Canarauletes Legalov, 2007 (including corrected p-distance). Taxon name is prefixed by the Collector's number and is followed by the locality and the GenBank accession number. The Neighbour Joining Tree is a subtree of currently 3517 samples of 1493 weevil species from the Western Palearctic (will be published soon in GenBank).

sufficient to classify A. gaditanus as a molecularly clearly distinguishable species within the subgenus Canarauletes (interspecific distances of sister species fluctuate only by $0.0 \%-2.5 \%$ in general).

A. Hoffmann (1953) mentions in his first description of Auletobius (C.) maroccanus that this species from Morocco (Moyen Moulouya, $1460 \mathrm{~m}$ ) is closely related to A. convexifrons Woll. Unfortunately, the phylogenetic relationships between Auletobius (C.) maroccanus from Morocco and the new species from Spain (see morphological comparison above) remain unclarified, because we have no comparative biomolecular data relating to Auletobius maroccanus. Therefore, in relation to this specific question, the description of the new species A. gaditanus is based exclusively on morphological comparison (see above).

In addition to the species A. garajonay, described by the second author from La Gomera (STÜBEN 2015) and which also occurs on El Hierro (STÜBEN 2018), there is a second species (Auletobius sp. 1) from the Canary Islands which remains undescribed (SтÜвEN, in prep.). Resolving the species complex around Auletobius anceps might be very difficult. This species varies considerably in its body size and eludes morphological analysis to this day. 


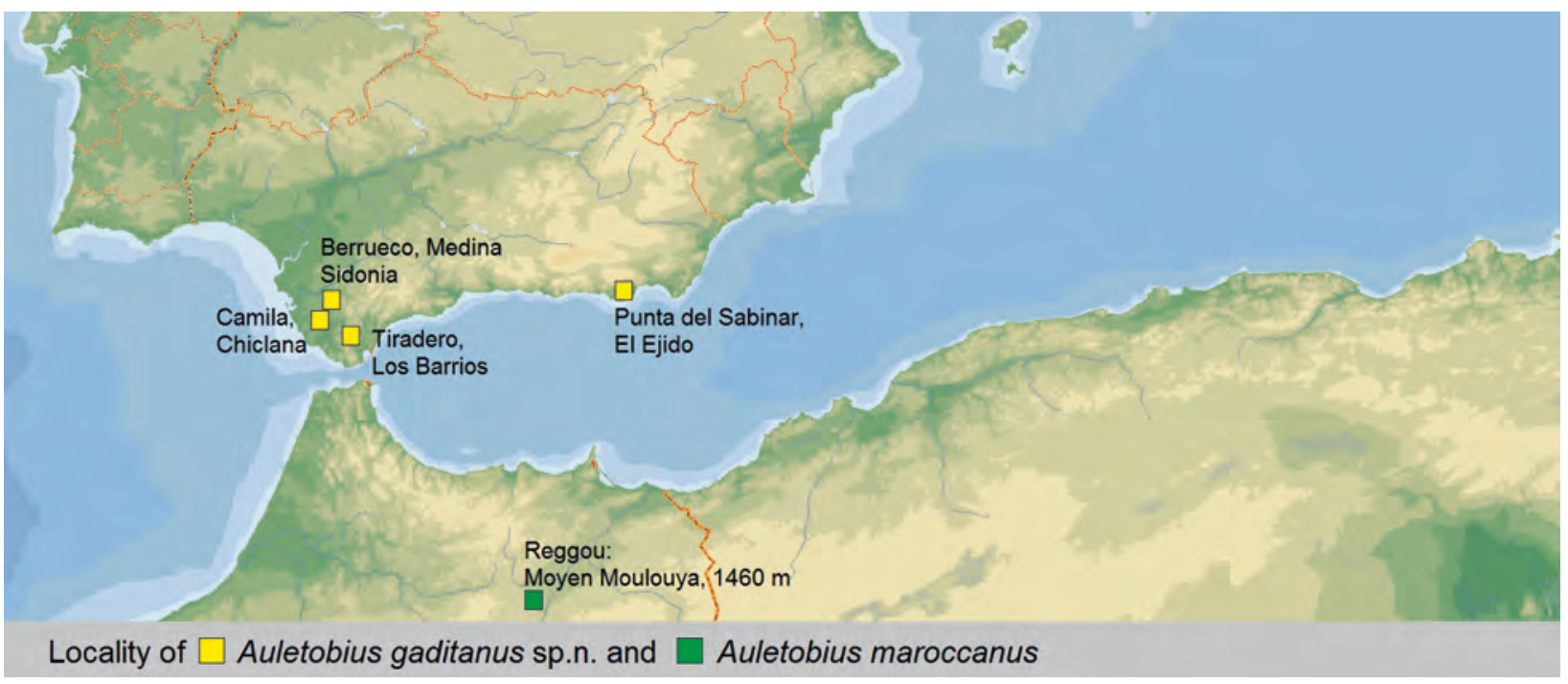

Fig. 5: Distribution of A. gaditanus and A. maroccanus.

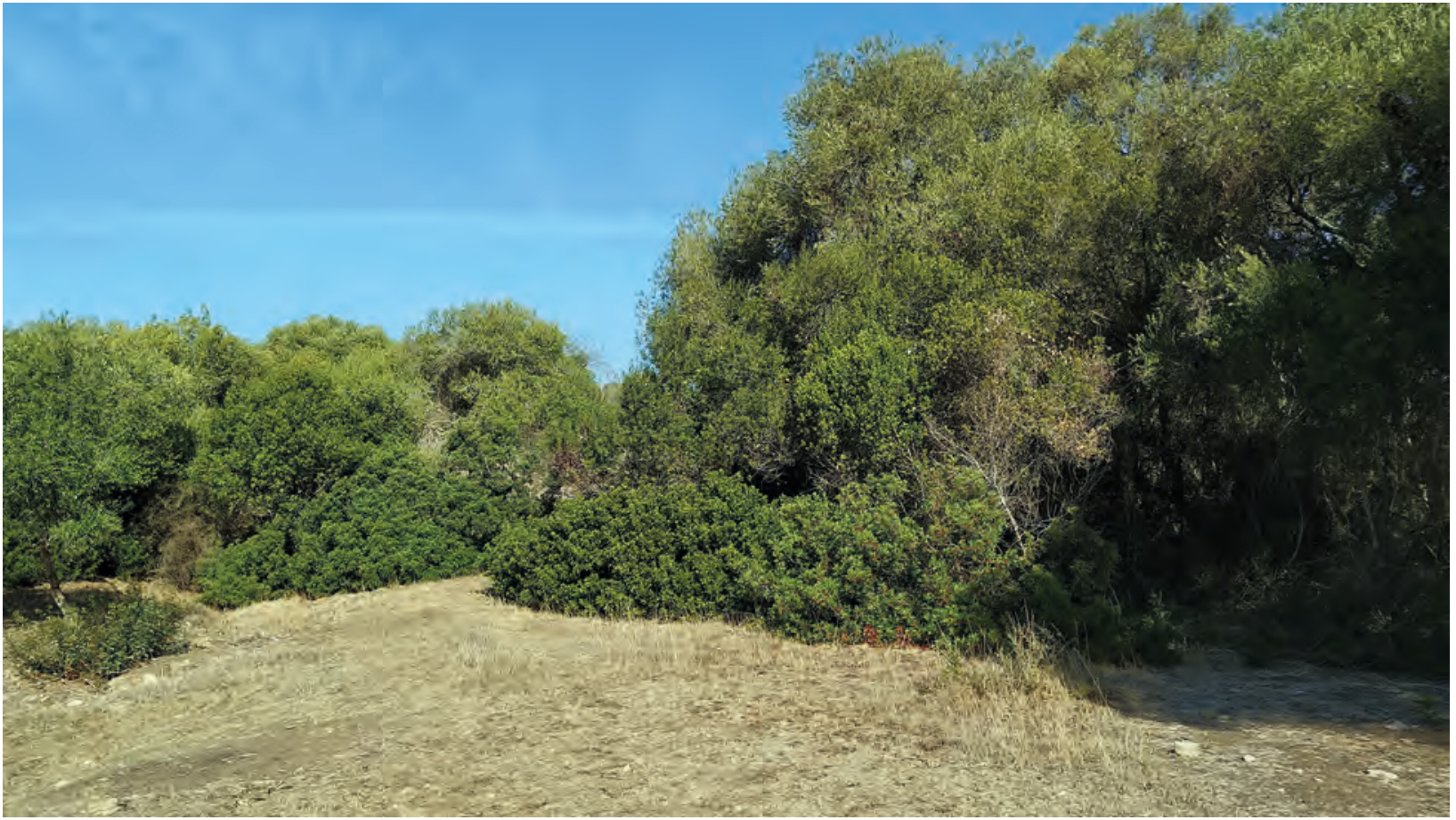

Fig. 6: Locus typicus of Auletobius (Canarauletes) gaditanus near Los Barrios; in the foreground Pistacia lentiscus on whose branches the new species was beaten (photo by A. Verdugo).

\section{Acknowledgements}

We thank Hélène Perrin and Christophe Rivier (MNHN, Paris) for providing us with images of the type of Auletobius maroccanus Hoffmann (but unfortunately not with the original type material). Our thanks also go to Leonardo Forbicione for his always cordial help in determining weevils. We are especially grateful to the Curculio Institute (Germany, Mönchengladbach), André Schütte from Zoologisches Forschungsmuseum Alexander Koenig (ZFMK, Germany, Bonn) and Katja Kramp from Senckenberg Deutsches Entomologisches Institute (Germany, Müncheberg) for the elaborate molecular analysis and free provision of the results, without which a first description can no longer manage today. - Keith Bensusan kindly revised the English text.

\section{References}

Alonso-Zarazaga, M. A. 2002: Lista preliminar de los Coleoptera Curculionoidea del área íbero-balear, con descripción de Melicius gen. nov. y nuevas citas. - Boletín de la Sociedad entomológica Aragonesa (S.E.A.) 31: 9-33. 
Hoffmann, A. 1953: Coléoptères phytophages nouveaux ou peu connus, de la faune paléarctique. - Revue Française d'Entomologie 20: 186-194.

LEgAlov, A. A. 2007: Leaf-rolling weevils (Coleoptera, Rhynchitidae, Attelabidae) of the world fauna. Monography - Novosibirsk: Agro-Siberia: 523 pp.

Morris, M. G. 2004: A review of the Macaronesian species of Auletobius Desbrochers, 1869 (Coleoptera, Curculionoidea, Rhynchitidae). - Vieraea 32: 29-47.

Skuhrovec, J.; Schön, K.; Stejskal, R.; Gosik, R.; Kresl, P. \& Trnka, F. 2012: Digital-WeevilDetermination for Curculionoidea of West Palaearctic. Rhynchitidae and Attelabidae. Snudebiller 13, Studies on taxonomy, biology and ecology of Curculionoidea, Mönchengladbach: Curculio-Institute: 138-161.

Stüвen, P. E. 2015: Auletobius (Canarauletes) garajonay sp. n. from La Gomera (Canary Islands) (Coleoptera:
Curculionoidea: Rhynchitidae). - Snudebiller 16, No. 244: 8 pp., CURCULIO-Institute: Germany / Mönchengladbach.

STÜBEN, P. E. 2018: Die Curculionoidea (Coleoptera) von El Hierro. - Snudebiller 19, No. 269: 56 pp., CURCULIO-Institute: Mönchengladbach.

StüBen, P. E. 2019: The Macaronesian Islands - an Encyclopedia of Curculionoidea (Coleoptera). Bibliografía.

LeCharancon:Catalogues \&Keys4.-http://www.curci.de, Mönchengladbach: CURCULIO-Institute (viewed in December 2019).

Verdugo, A. 2019: Algunos registros de Curculionoidea de Andalucía (Insecta: Coleoptera). - Revista gaditana de Entomología 1: 57-69.

Wollaston, T. V. 1864: Catalogue of the Coleopterous insects in the collection of the British Museum. British Museum, London.

\section{Appendix 1}

We are firmly convinced that molecular sequences should be part of the scientific article in which they were first published. This is especially true in the first description of a new taxon. The fact that they are also deposited separately and furthermore in GenBank is undoubtedly an additional safeguard for long-term accessibility.

We provide the $\mathrm{CO} 1$ sequence data of the new species in fasta format. The content can be copied and pasted into a *.fasta text file which can be imported easily in any bioinformatics application.

Auletobius gaditanus spec. nov. / E: Cádiz, Los Barrios, Pista a Tiradero / collector’s no: 3188-AVE / GenBank: MN627733

TACTTTATATTTTATTTTTGGGGCTTGAGCTGGAATAGTAGGAACCTCCCTAAGCTTATTAATCCGAGCTGAGCTAGGAAACCCTGGTTCATTAATTGGAGACGATCAAATTTATAATGTTATTGTTACTGCTCATGCTTTTATCATAATTTTTTTTATAGTTATACCAATTATAATTGGTGGATTTGGAAATTGGCTTGTTCCCTTAATATTAGGGGCCCCTGACATAGCCTTTCCTCGAATAAATAACATAAGATTTTGACTACTTCCCCCATCATTAAGTTTATTAATTATAAGAAGAATTGTAGAAAAAGGAGCTGGTACAGGATGAACTGTATACCCCCCGCTATCTTCTAATATTGCCCATGGAGGATCTTCAGTAGATTTAGCTATTTTTAGTCTTCATTTAGCAGGAATTTCCTCTATTTTAGGGGCTGTAAATTTTATTTCAACAGTAATTAATATACGGCCAGAAGGAATAAACTTAGACCGAACTCCATTATTTGTATGAGCAGTTTTAATTACTGCAATTTTATTATTGCTTTCATTACCCGTTCTTGCAGGAGCAATTACTATACTTCTTACAGATCGAAATATCAATACATCCTTCTTTGATCCGGCTGGTGGGGGAGACCCAATTCTTTATCAACATTTATTT

Auletobius gaditanus spec. nov. / E: Cádiz, Medina Sidonia, El Berrueco / collector's no: 3189-AVE / GenBank: MN627734

TACTTTATATTTTATTTTTGGGGCTTGAGCTGGAATAGTAGGAACCTCCCTAAGCTTATTAATCCGAGCTGAGCTAGGAAACCCTGGTTCATTAATTGGAGACGATCAAATTTATAATGTTATTGTTACTGCTCATGCTTTTATCATAATTTTTTTTATAGTTATACCAATTATAATTGGTGGATTTGGAAATTGGCTTGTTCCCTTAATATTAGGGGCCCCTGACATAGCCTTTCCTCGAATAAATAACATAAGATTTTGACTACTTCCCCCATCATTAAGTTTATTAATTATAAGAAGAATTGTAGAAAAAGGAGCTGGTACAGGATGAACTGTATACCCCCCGCTATCTTCTAATATTGCCCATGGAGGATCTTCAGTAGATTTAGCTATTTTTAGTCTTCATTTAGCAGGAATTTCCTCTATTTTAGGGGCTGTAAATTTTATTTCAACAGTAATTAATATACGGCCAGAAGGAATAAACTTAGACCGAACTCCATTATTTGTATGAGCAGTTTTAATTACTGCAATTTTATTATTGCTTTCATTACCCGTTCTTGCAGGAGCAATTACTATACTTCTTACAGATCGAAATATCAATACATCCTTCTTTGATCCGGCTGGTGGGGGAGACCCAATTCTTTATCAACATTTATTT 